\title{
Rancang Bangun Sistem Pakar Berbasis WEB untuk Mendiagnosis Jenis Burung Air: Waterbird Exsys
}

\author{
Nida'ul Hasanati*, Dinda Fitriasari \\ Program Studi Teknik Informatika, Fakultas Sains dan Teknologi, \\ Universitas Al Azhar Indonesia, Jl. Sisingamangaraja, Jakarta 12110 \\ "Penulis untuk korespondensi: nida@uai.ac.id
}

\begin{abstract}
Abstrak - Makalah ini menyajikan sebuah sistem pakar berbasis web untuk mendiagnosa jenis burung, terutama burung air. Kebanyakan Burung air bermigrasi dari satu tempat ke tempat lainnya yang jauh, dan beberapa dari mereka hanya berhenti sesaat. Mereka sering pindah dari tempat kelahiran merekake tempat mereka berkembang biak dengan jarak yang sangat jauh. Kondisi ini membuat peneliti atau orang-orang yang peduli pada lingkungan, sulit untuk mendiagnosis berbagai jenis spesies burung air yang mereka temukan. Sistem pakar ini dimaksudkan untukmembantu mereka untuk memecahkan masalah umum identifikasi spesies burung air dengan pendekatan yang efisien dan orientasi hasil. Pengetahuan sistem pakar ini dimasukkan ke dalam basis pengetahuan yang terintegrasi dengan menggunakan aturan "jika-maka". Kesimpulan dari sistem pakar ini diambil dengan menggunakan mekanisme inferensi backward chaining. Dengan pengetahuan yang akurat dan pengujian yang serius, sistem ini dapat membantu proses diagnosis cepat dan akurat. Sistem pakar berbasis web juga dapat digunakan sebagai alat pendidikan di bidang Biologi, terutama Ornitologi, yang dapat dimanfaatkan oleh masyarakat umum atau pihak yang bersangkutan dengan kelestarian lingkungan [1].
\end{abstract}

Abstrack - This paper presents a web-based expert system for diagnosing bird species, especially waterbird. Waterbird are migratory birds that move from one place to other distant places, and some of them just simply stopped. They often move from their birthplace to where they breed with a very far distance. This condition make researchers or the persons, who concerned for the environment, difficult to diagnose the different kind of waterbird species that they found. This expert system is intended to help them to solve the general problem of identification of Waterbird species with efficient approach and result-orientation. This expert system uses organized knowledgeas arule "ifthen", and allthe knowledge for diagnostic processing are incorporated into an integrated knowledge base. Conclusion from the expert system is retrieved by using the inference mechanism of backwardchaining. By providing accurate knowledge and seriously testing, the system can help the diagnosis process quickly and accurately. This web based expert system also can be used as an educational tool in the field of Biology, especially Ornithology, which can be utilized by the general public or the parties concerned with environmental sustainability.

Keywords - web based expert system, biology, waterbird, e2glite expert system shell, backward chaining

\section{PENDAHULUAN}

$\mathrm{B}$ urung merupakan jenis hewan ciptaan Allah yang memiliki karakteristik yang berbeda dari vertebrata lainnya. Tercatat lebih dari 1.542 jenis burung hidup di Indonesia. Di KepulauanSunda Besar, khususnya Pulau Jawa dan Bali, tercatat 289 jenis burung.Di antara banyak jenis burung, ada satu jenis burung yang unik, yaituburung air (waterbird). Burung air merupakan salah satu jenis satwa yang biasa ditemukan di daerah perairan atau lahan basah.

Hal yang menarik dari burung air adalah burung air sering berpindah tempat atau migrasi dari tempat lain yang jauh, dan diantaranya ada yang sekedar 
singgah. Burung ini sering berpindah dari tempat mereka berkembang biak ke tempat kelahirannya dengan menempuh jarak yang sangat jauh. Kehadirannya dapat dijadikan sebagai indikator penting dalam mengkaji mutu dan produktivitas suatu lingkungan lahan basah (bio-indicator).

Terdapat sekitar 120 jenis burung air dengan daerah penyebarannya meliputi Pulau Jawa dan Bali, baik yang merupakan burung pendatang maupun menetap. Banyaknya jenis burung air pendatang baru yang bermunculan menyebabkan peneliti mengalami kesulitan dalam mengidentifikasi jenisnya.Dari hasilwawancara dengan Bapak Yus Rusila Noor, selaku Senior ProgrammeOfficer dari Wetlands International-Indonesia Programme, Ibu Dewi Elfidasari dan Bapak Ferry Hasudungan, selaku peneliti burung air, didapatkan beberapa permasalahan yang timbul dalam proses pengidentifikasian jenis burung air, yang timbul dalam proses pengidentifikasian jenis burung air, yang disimpulkan sebagai berikut:

a. Pakar burung air di Indonesia jumlahnya masih terbatas sehingga menyulitkan peneliti atau pengamat untuk berkonsultasi dengan pakar dalammenentukan prinsip-prinsip identifikasi.

b. Dasar pedoman identifikasi burung air masih sulit didapatkan (langka), sehingga antar peneliti atau pengamat sering terjadi perbedaan deskripsi fisik burung air.

c. Ketika melakukan pengamatan di lapangan, waktu yang diperlukan untuk menentukan jenis burung air relatif lama, karena pengamat harus mencatat dan mencocokkan deskripsi fisik tubuhnya di dalam buku pedoman.

d. Banyak bermunculan jenis burung air baru yang belum terdokumentasi.

e. Belum adanya sistem yang menyimpan pengetahuan burung air dan mampu bekerja layaknya pakar dalam mengidentifikasi jenis burung air.

Untuk itu, diperlukan suatu upaya menciptakan pakar-pakar dalam mengidentifikasi jenis burung air yang terotomasi, yaitu salah satunya yang menjadi tujuan penulis adalah membuat sistem pakar untuk diagnosis jenis burung air.

Sistem Pakar Diagnosis Jenis Burung Air merupakan suatu sistem yang berusaha mengadopsi pengetahuan pakar jenis burung air ke dalam komputer, sehingga komputer dapat menyelesaikan masalah identifikasi jenis burung air.
Terdapat beberapa rumusan masalah dalam pengembangan Waterbird Exsys ini, antara lain:

a. Bagaimana mengetahui jenis burung air berdasarkan karakteristik fisik tubuhnya?

b. Bagaimana cara memetakan dan memformulasikan pengetahuan seorang pakar di bidang identifikasi burung air ke dalam basis pengetahuan sistem pakar?

c. Bagaimana mengembangkan sistem pakar yang bisa digunakan untuk mendiagnosis jenis burung air berdasarkan hasil pemetaan dan formulasipengetahuan pakar?

Karena keterbatasan waktu, maka penelitian yang akan dilakukan ini terbatas pada:

a. Jenis burung air yang akan dibahas mencakup 120 jenis dengan daerah penyebarannya meliputi Pulau Jawa dan Bali, yang terdiri dari family Podicipedidae, Phalacrocoracidae, Pelecanidae, Ardeidae, Ciconiidae, Threskiornithidae, Anatidae, Rallidae, Heliornithidae, Jacanidae, Rostratulidae, Charadriidae, Scolopacidae, Recurvirostridae, Phalaropodidae, Burhinidae, Glareolidae, dan Laridae.

b. Sistem yang dibangun adalah sebuah sistem yang hanya mendiagnosis jenisburung air dan memberikan solusi berupa penentuan jenis burung air tersebutberdasarkan morfologi (karakteristik/ciri) fisik tubuhnya.

c. Pembuatan sistem pakar akan menggunakan alat pengembangan berupa shell, yaitu e2gLite Expert SystemShell

Dengan adanya Sistem Pakar Diagnosis Jenis Burung Air Berbasis Web (Waterbird Exsys), diharapkan dapat menjawab berbagai permasalahan yang dihadapi dan dapat memberikan manfaat antara lain:

a. Penentuan jenis burung air yang merupakan hasil akhir dari proses identifikasi dapat dengan mudah diketahui karena pedoman dasarnya telahtersimpan di dalam sistem.

b. Meminimalisasi waktu yang dibutuhkan untuk menentukan jenis burung air.

c. Solusi yang dibuat berbasis web sehingga mudah di akses dimana saja selama terkoneksi dengan jaringan internet daninformasi mengenai jenis burung air dapat dengan segera disebarluaskan [2].

Basis pengetahuan yang berisi dasar pedoman dalam proses identifikasi jenis burung air dapat 
diperbarui dan dikembangkan sehingga solusi yang diinginkan tetap tersedia.

Dengan pengembangan SistemPakar Diagnosis Jenis Burung Air Berbasis Web (Waterbird Exsys), juga diharapkan dapat dapat membantu peneliti, pelajar, mahasiswa dan pihak-pihak yang peduli pada kelestarian lingkungan dalam mengidentifikasi jenis burung air; mengatasi jumlah pakar di bidang burung air yang jumlahnya masih terbatas, karena aplikasi ini dapat diperbanyak sesuai dengan kebutuhan secara legal; berkontribusi dalam karya ilmiah, khususnya yang berhubungan dengan sistem pakar untuk melakukan penelitian lebih lanjut.

\section{TINJAUAN PUSTAKA}

\subsection{Biologi Burung Air}

Secara umum, morfologi burung memiliki sejumlah perbedaan dengan vertebrata lainnya. Tubuh burung dapat dibedakan atas: Caput (kepala), Cervix (leher), Truncus (badan), serta organ ekstremitas yang terdiri dari ekstremitas mayor (sayap) dan inferior (tungkai) [3].

Kehidupan burung air banyak tergantung kepada keberadaan lahan basah. Mereka menjadikan lahan basah serta tegakan tumbuhan yang ada diatasnya sebagai tempat untuk mencari makan, beristirahat, atau berkembang biak. Beberapa jenis lahan basah yang sering dijadikan sebagai habitat burung air adalah sebagai berikut [3]:

a. Mangrove dan hamparan lumpur (mudflat),

b. Hutan rawa air tawar dan gambut,

c. Rawa rumput (grass swamp), savana dan rawa herba (herbaceous swamp).

\subsection{Sistem Pakar}

Sistem pakar adalah cabang ilmu kecerdasan buatan (artificial intelligence), yang merupakam sistem yang berusaha mengadopsi pengetahuan manusia ke dalam komputer, agar komputer dapat menyelesaikan masalah yang biasa dilakukan oleh para pakar [4].

Komponen sistem pakar didasarkan pada 2 (dua) jenis lingkungan yang membentuknya, yaitu lingkungan pengembangan (development environment) dan lingkungan konsultasi (consultation environment) [5].
Secara umum, sistem pakar terdiri dari 4 (empat) macam komponen utama, yaitu:
a. Antarmuka Pengguna (User Interface)
b. Basis Pengetahuan (Knowledge Base)
Basis pengetahuan mencakup dua elemen dasar, yaitu: fakta dan aturan (rules)
c. Mesin Inferensi (Inference Machine)
d. Memori Kerja (Working Memory).

Selain keempat komponen tersebut, untuk mendukung pekerjaan sistem pakar agar dapat berjalan dengan baik dan layaknya seorang pakar, maka terdapat 2 (dua) komponen tambahan, yaitu:

a. Fasilitas Penjelasan (Explanation Facility)

b. Fasilitas Akuisisi Pengetahuan (Knowledge Acquisition Facility).

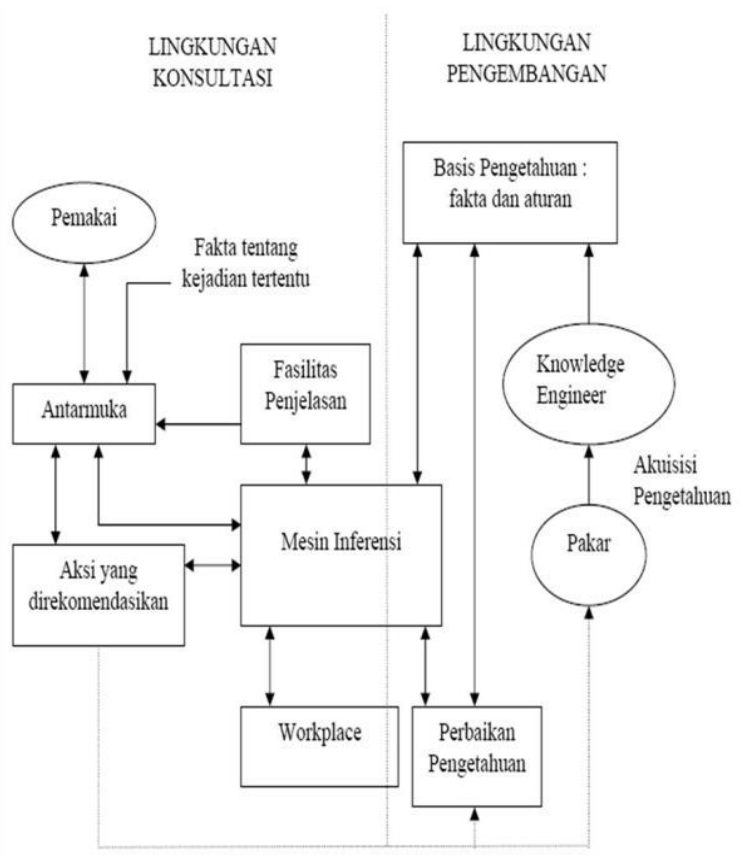

Gambar 1. Komponen Sistem Pakar [3]

\subsection{Pengembangan Sistem Pakar}

Dalam mengembangkan suatu sistem pakar, secara rinci terdapat 10 (sepuluh) langkah yang dapat dilakukan pengembangan sistem pakar. Kesepuluh langkah tersebut diperlihatkan pada flowchart berikut ini. 

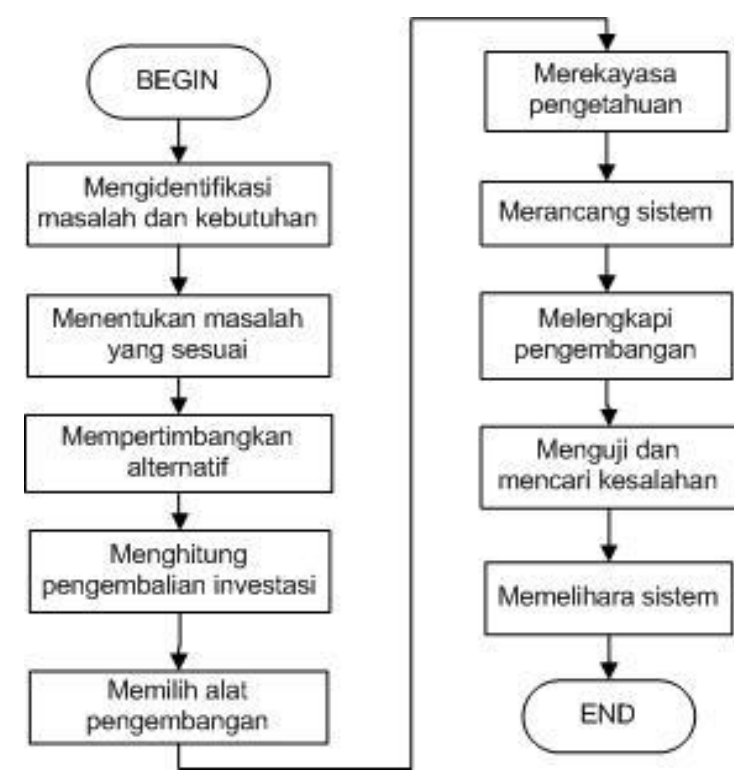

Gambar 2. Sepuluh Langkah Pengembangan Sistem Pakar [6]

\section{METODOLOGI PENELITIAN}

Metodologi yang digunakan penulis dalam melakukan penelitian, yaitu:

1. Studi kepustakaan, dengan melakukan pencarian informasi pada tulisan ilmiah dan buku mengenai dasar pedoman identifikasi burung air dan sistem pakar, serta tambahan wawasan dari majalah, internet, dan sebagainya.

2. Studi Lapangan, yang meliputi:

a. Wawancara, kepada:

i. Pakar burung air, yaitu Ibu Dewi Elfidasari dan Bapak Ferry Hasudungan, selaku peneliti burung air.

ii. Pengguna sistem, yaitu peneliti, mahasiswa (Mahasiswa Biologi Universitas Al Azhar Indonesia), dan pecinta kelestarian burung (Bapak Yus Rusila Noor, selaku Senior Programme Officer dari Wetlands InternationalIndonesia Programme).

b. Observasi, dengan melihat secara langsung berbagai jenis burung air di kebun binatang Ragunan dan Cagar Alam Pulau Dua Serang.

3. Metodologi Pengembangan Sistem

Terdapat 6 (enam) langkah dalam membangun sistem pakar ini [5], yaitu: a. Memilih tool.

b. Identifikasi masalah dan menganalisis pengetahuan untuk dimasukkan ke dalam sistem pakar.

c. Merancang sistem, dengan membuat tabel keputusan dan kaidah produksi.

d. Membangun prototipe sistem menggunakan tool.

e. Melakukan uji coba dan memperbaiki sistem sehingga sesuai kriteria yang diinginkan.

f. Melakukanpemeliharaan sistem dan pemutakhiran sistem jika diperlukan.

\section{HASIL DAN PEMBAHASAN}

\subsection{Memilih Alat Pengembangan Sistem Pakar}

Sistem pakar dapat dikembangkan melalui 2 cara, yaitu dengan menggunakan bahasa pemrograman atau shell. Bahasa pemrograman terbagi ke dalam 2 jenis, yaitu bahasa pemrograman umum (C, Java, PHP) dan bahasa pemrograman khusus rekayasa pengetahuan (Prolog dan LISP). Adapun shell merupakan salah satu program generator sistem pakar yang di dalamnya telah mencakup komponen antarmuka, mesin inferensi, fasilitas penjelasan, dan basis pengetahuan yang masih kosong [5].

Untuk menentukan alat pengembangan apa yang sesuai dengan domain masalah yang ditelaah, perlu dilakukan perbandingan beberapa alternatif alat pengembangan sistem pakar. Pada kasus ini, alternatif-alternatif alat pengembangan yang akan dibandingkan antara lain yaitu: bahasa pemrograman PHP, Prolog, Java Expert System Shell (JESS) [7][8], dan e2gLite Expert System Shell. Berikut hasil perbandingan keempat alternatif tersebut yang disajikan dalam Tabel 1 pada lampiran.

Berdasarkan analisis perbandingan di atas, maka pengembangan sistem pakar diagnosis jenis burung air ini akan menggunakan e2gLite Expert System Shell, karena shell tersebut cocok untuk jenis sistem pakar diagnosis [9].

e2gLite Expert System Shell,merupakan shell sistem pakar berbasis aturan (rule-based expert system shell), yang dikembangkan oleh eXpertise2Go [10], terdiri dari 2 (dua) mesin (engine), yaitu e2gRuleEngine dan e2gRuleWriter. Keduanya mesin ini merupakan Java applet yang ditempelkan 
di halaman Web page sehingga dapat dijalankan user melalui Web browser.

e2gRuleEngine berfungsi sebagai mesin inferensi, dan e2gRuleWriter mesin untuk memasukkan pengetahuan ke dalam basis pengetahuan sistem pakar.

\subsection{Akuisisi Pengetahuan (Knowledge Acquisition)}

Pada tahap akuisisi pengetahuan (pengumpulan data-data dari pakar), dilakukan beberapa cara untuk mendapatkan bahan pengetahuan mengenai jenis burung air yang dibutuhkan dalam membangun basis pengetahuan. Adapun cara-cara yang telah dilakukan antara lain:

1. Studi kepustakaan. Bahan pengetahuan bersumber dari buku, jurnal ilmiah, dan internet.

2. Wawancara pakar. Bahan pengetahuan didapat dari hasil tanya jawab dengan para pakar mengenai cara-cara identifikasi jenis burung air.

3. Observasi lapangan. Melakukan pengamatan burung air secara langsung (tamankonservasi burung).

Dari hasil akuisisi pengetahuan, didapat pengetahuan yang menjadi dasar dalam tahapan rekayasa pengetahuan. Salah satu contoh pengetahuan burung air berfamili sama, yang didapat dari hasil akuisisi pengetahuan yaitu:

\section{Australasian Grebe (Tachybaptus novaehollandiae)}

Deskripsi: Berukuran kecil $(24 \mathrm{~cm})$, bertubuh pendek dan gemuk. Sangat mirip Little Grebe, perbedaannya adalah tubuh bagian bawah putih, sayap lebih banyak berwarna putih, serta tenggorokannya hitam (bukan merah) pada masa berbiak.Garis cokelat buah berangan di belakang mata memisahkan mahkota dari tengkuknya yang hitam dengan dagu dan tenggorokannya yang hitam keabu-abuan. Iris putih sampai kuning, paruh hitam dengan warna putih pada ujungnya, kaki hijau zaitun sampai hitam.

Habitat: Sering mengunjungi danau, rawa, atau sawah yang berair bersih dan banyak ditumbuhi tumbuhan air.
2. Little Grebe (Tachybaptus ruficollis)

Deskripsi: Berukuran kecil $(25 \mathrm{~cm})$, berwarna gelap, bertubuh pendek dan gemuk, mirip bebek. Pada waktu berbiak, bulu di sekitar tenggorokan dan leher berwarna kemerahan. Mahkota dan tengkuk cokelat gelap. Tubuh bagian atas cokelat, tubuh bagian bawah keabu-abuan. Iris kuning sampai merah tua, paruh hitam, kaki abu-abu kebiruan.

Habitat: Sering mengunjungi danau, rawa, atau sawah yang berair bersih dan banyak ditumbuhi tumbuhan air.

Berdasarkan pengetahuan-pengetahuan yang telah diakuisisi dari literatur dan pakar, maka didapatkan klasifikasi pembagian tubuh burung air yang akan digunakan sebagaidasar identifikasi. Klasifikasi bagian tubuh burung air dengan diurutkan berdasarkan prioritas ciri fisiknyanya, yaitu sebagai berikut:
1. Ukuran tubuh

2. Bentuk tubuh

3. Ukuran paruh

4. Bentuk paruh

5. Ukuran leher

6. Bentuk kaki

7. Ukuran kaki

8. Bentuk Ekor
9. Habitat
10. Warna paruh
11. Warna kaki
12. Warna mahkota kepala
13. Warna leher belakang
14. Warna leher depan
15. Warna badan atas
16. Warna badan bawah

Selanjutnya, klasifikasi pembagian tubuh burung air tersebut akandijadikan pedoman dalam rekayasa pengetahuan dan perancangan basis pengetahuan.

\subsection{Rekayasa Pengetahuan}

Pengetahuan yang akan direpresentasikan dalam sistem pakar ini adalah data morfologi (karakteristik/ciri-ciri fisik) burung air yang diperoleh dari hasil akuisisi pengetahuan proses pengamatan dan studi kepustakaan.

Penulis melakukan 2 bentuk representasiyaitu: merancang tabel keputusan dan kaidah produksi. Hasil akhir berupa himpunan kaidah/rules yang akan dimasukkan dalam basis pengetahuan [11].

\subsubsection{Tabel Keputusan (Decision Table)}

Tabel 2 pada lampiran digunakan untuk menggambarkan jenis burung air beserta ciri-ciri fisiknya. Tabel ini terbagi ke dalam 2 (dua) bagian, yaitu kondisi tubuh dan jenis burung. Simbol huruf 
A-J pada tabel keputusan menjelaskan tentang jenis/nama burung air. Simbol * menunjukkan hubungan (konektifitas) antara jenis burung air dengan kondisi tubuh yang dimiliki burung tersebut.

Domain masalah dibatasi pada 120 jenis burung air yang mencakup wilayah Pulau Jawa dan Bali, dengan kemungkinan nilai/pilihan kondisi tubuh sebanyak 163 dalam 10 kategori kondisi ciri fisiknya.

Tabel 2 contoh yang mewakili 10 jenis burung air, dengan 22 nilai/pilihan kondisi tubuh dalam 4 kategori kondisi ciri fisiknya.

\subsubsection{Kaidah Produksi}

Kaidah produksi dibentuk dari himpunan-himpunan kaidah yang mengacu kepada hasil pemetaan pada pohon keputusan [12]. Berikut contoh 2 kaidah produksi burung air berfamili sama, dari hasil pemetaan dari 120 kaidah, yaitu:

\section{Kaidah 1: Australasian Grebe}

IF ukuran tubuh lebih besar dari burung kutilang tapi lebih kecil dari bebek $(20-39 \mathrm{~cm})$

AND bentuk tubuh seperti bebek/mentok (duck like)

AND ukuran paruh lebih pendek dari kepala

AND bentuk paruh ramping/agak besar dan paruh atas sedikit melengkung

AND ukuran leher sedang

AND bentuk kaki lobate (bercuping)

AND ukuran kaki pendek

AND bentuk ekor bulat (rounded tail)

AND habitatrawa rumput (grass swamp), savana dan sawah

AND warna paruh hitam/abu-abu tua/abu-abu kebiruan

AND warna kaki hijau keabuan (zaitun)

AND warna mahkota kepala cokelat tua/cokelat kemerahan

AND warna leher belakang cokelat tua/cokelat kemerahan

AND warna leher depan hitam/kehitaman

AND warna badan atas cokelat

AND warna badan bawah putih/keputihan

Kaidah 2: Little Grebe

IF ukuran tubuh lebih besar dari burung kutilang tapi lebih kecil daribebek $(20-39 \mathrm{~cm})$

AND bentuk tubuh seperti bebek/mentok (duck-like)
AND ukuran paruh lebih pendek dari Kepala

AND bentuk paruh ramping/agak besar dan paruh atas sedikitmelengkung

AND ukuran leher sedang

AND bentuk kaki lobate (bercuping)

AND ukuran kaki pendek

AND bentuk ekor bulat (rounded tail)

AND habitat rawa rumput (grass swamp), savana dan sawah

AND warna paruh hitam/abu-abu tua/abu-abu kebiruan

AND warna kaki abu-abu gelap/abu-abu kebiruan

AND warna mahkota kepala cokelat tua/cokelat kemerahan

AND warna leher belakang cokelat tua/cokelat kemerahan

AND warna leher depan merah/kemerahan

AND warna badan atas cokelat

AND warna badan bawah abu-abu

\subsection{Perancangan Basis Pengetahuan}

Basis pengetahuan merupakan tempat untuk menyimpan fakta-fakta serta aturan-aturan mengenai jenis burung air yang telah dihasilkan dari prosesrepresentasi pengetahuan.

Shell memiliki basis pengetahuan yang masih kosong. Basis pengetahuan shell ini bersifat dinamis, sehingga kita tinggal memasukkan pengetahuan Waterbird Exsys berdasarkan format representasi pengetahuan e2gLightExpert System Shell yang tersedia, yaitu berbasis aturan (rulebased reasoning), dalam bentuk : IF-THEN.

Basis pengetahuan ini terdiri dari 4 (empat) elemen utama [5], yaitu:

a. REM statements

b. RULE descriptions

c. PROMPT definitions.

d. GOAL definitions.

Berikut ini adalah bentuk basis pengetahuan waterbird exsys dengan nama file burung_air.kb: 


\begin{tabular}{|c|}
\hline $\begin{array}{l}\text { REM Generated by v1.00a of e2gRuleWriter } \\
\text { 07/28/2010 09:04 from: burung_air.kbt }\end{array}$ \\
\hline $\begin{array}{l}\text { If [ukuran] = "Kecil }(10-45 \mathrm{~cm}) " \text { and } \\
\text { [bentuk paruh] = "Pendek \& paruh atas sedikit } \\
\text { melengkung" and } \\
\text { [warna paruh] = "Hitam / kehitaman" and } \\
\text { [ukuran leher] = "Pendek" and } \\
\text { [bentuk ekor] = "Pendek/sedang \& agak meruncing di } \\
\text { ujungnya" and } \\
{[\text { habitat] = "Di dalam/sekitar air tawar atau di area }} \\
\text { sawah basah/rawa" } \\
\text { Then [famili burung] = "Grebes" }\end{array}$ \\
\hline $\begin{array}{l}\text { If [ukuran] = "Sedang (46-79 cm)" and } \\
\text { [bentuk paruh] = "Sedang, agak besar \&paruh atas } \\
\text { sedikit melengkung" and } \\
\text { [ukuran leher] = "Sedang" and } \\
\text { [bentuk ekor] = "Panjang / panjang dan kaku" and } \\
\text { [habitat] = "Di dalam/sekitar air tawar atau di area } \\
\text { sawah basah/rawa" } \\
\text { Then [famili burung] = "Cormorants" } \\
\text { RULE [Australian Little Grebe?] } \\
\text { If [famili burung] = "Grebes" and } \\
\text { [warna leher] = "Hitam / kehitaman" and } \\
\text { [warna badan atas] = "Cokelat / cokelat tua" and } \\
\text { [warna badan bawah] = "Putih" and } \\
\text { [warna kaki] = "Kuning langsat (olive)" } \\
\text { Then [identifikasi burung] = "Australian Little Grebe" }\end{array}$ \\
\hline $\begin{array}{l}\text { If [famili burung] = "Grebes" and } \\
\text { [warna leher] = "Merah / kemerahan" and } \\
\text { [warna badan atas] = "Cokelat / cokelat tua" and } \\
\text { [warna badan bawah] = "Abu-abu / keabuan" and } \\
\text { [warna kaki] = "Abu-abu gelap / abu-abu } \\
\text { kebiruan / abu-abu kehijauan / biru keabuan" } \\
\text { Then [identifikasi burung] = "Little Grebe" }\end{array}$ \\
\hline $\begin{array}{l}\text { If [famili burung] = "Cormorants" and } \\
\text { [jambul] = true and } \\
\text { [warna paruh] = "Cokelat" and } \\
\text { [bercak di leher] = true and } \\
\text { [warna leher] = "Hitam / kehitaman" and } \\
\text { [warna badan atas] = "Biru tua / hijau tua / hitam } \\
\text { mengkilap" and } \\
\text { [warna badan bawah] = "Biru tua / hijau tua / hitam } \\
\text { mengkilap" and } \\
\text { [warna kaki] = "Hitam / kehitaman" } \\
\text { Then [identifikasi burung] = "Little Cormorant" }\end{array}$ \\
\hline $\begin{array}{l}\text { RULE [Little Pied Cormorant?] } \\
\text { If [famili burung] = "Cormorants" and } \\
\text { [warna paruh] = "Kuning" and } \\
\text { [warna leher] = "Putih" and } \\
\text { [warna badan atas] = "Hitam / kehitaman" and } \\
\text { [warna badan bawah] = "Putih" and }\end{array}$ \\
\hline
\end{tabular}

[warna kaki] = "Hitam / kehitaman"

Then [identifikasi burung] = "Little Pied Cormorant"

RULE [Little Black Cormorant?]

If [famili burung] = "Cormorants" and

[warna paruh $]=$ "Abu-abu / abu-abu tua / abu-abu

kebiruan" and

[warna leher] $=$ "Hitam / kehitaman" and

[warna badan atas] = "Biru tua / hijau tua / hitam

mengkilap" and

[warna badan bawah] = "Biru tua / hijau tua / hitam

mengkilap" and

[warnakaki] = "Hitam / kehitaman"

Then [identifikasi burung] = "Little Black Cormorant"

..............

PROMPT [ukuran] ForcedChoice CF

"Bagaimanakah ukuran burung yang dimaksud?"

"Kecil (10-45 cm)"

"Sedang (46-79 cm)"

"Besar (80-129 cm)"

"Sangat besar (> $129 \mathrm{~cm}) "$

....................

GOAL [identifikasi burung]

MINCF 70

Basis pengetahuan e2gLight berbasis teks (text based) berekstensi file.kb. Terdapat 2 cara untuk membuatnya, yaitu pertama, diketik manual melalui editor seperti notepad disimpan dengan extensi file.kb, kedua menggunakan engine dari e2gLight yang disediakan yaitu e2gRuleWriter. E2gRuleWriter merupakan fasilitas akuisisi pengetahuan dalam bentuk Graphical User Interfece (GUI), berbasis decision table, yang dapat menyimpan pengetahuan dalam bentuk file berekstensi.kbt dan kemudian menerjemahkan dapat knowledge tersebut ke file berekstensi.kb. Gambar 3 adalah antarmuka e2gRuleWriterengine tempat menginputkan basis pengetahuan.

Modul e2gRuleWriter memiliki beberapa fitur penting yang digunakan untuk mengisi basis pengetahuan, yaitu:

1. Conditions: fitur untuk mengisi premispremis atau kategori kondisi yangmengacu kepada tabel keputusan yang telah dibuat.

2. Actions: fitur untuk mengisi tujuan (goal) dari premis-premis atau kategorikondisi yang ada.

3. Rule: fitur untuk mengisi aturan-aturan pembentuk kaidah produksi yang didasarkan pada nilai dari kategori kondisi dan tujuan yang sebelumnya telah ditentukan. 
4. New List Value: kemungkinan nilai dari kondisi/pilihan nilai dari tiap konsisi.

5. Prompt: kalimat pertanyaan yang ditampilkan.

6. Prompt Type: Tipepertanyaan/bentuk input yang ditampilkan.

7. Allow CF Input: Input faktor kepastian.

Inference engine sistem pakarini (e2gRuleEngine) menggunakan metode inferensi runut balik (backward chaining). Runut balik digunakan pada saat melakukan penelusuran pencarian fakta-fakta atau kondisi yang sesuai dengan konklusi (hipotesis awal).

Data yang digunakan dalam inferensi diperoleh dari jawaban yang diberikan pemakai atas pertanyaan mengenai kondisi burung air yang diajukan oleh sistem. Sistem tidak akan menanyakan pertanyaan yang sudah pernah diberikan. Oleh karena itu diperlukan penyimpan data pertanyaan yang pernah diajukan (dalam working memory).

\subsection{Perancangan Antarmuka}

E2gLite Expert System Shell terbagi ke dalam 2 (dua) jenis antarmuka, yaitu antarmuka bagi perekayasa pengetahuan (knowledge engineer) dan antarmuka bagi pemakai akhir. Antarmuka bagi perekayasa pengetahuan (e2gRuleWriter) digunakan untuk memasukkan fakta-fakta dan aturan-aturan ke dalam basis pengetahuan yang terlihat dalam Gambar 4. Antarmuka bagi pemakai akhir menjelaskan tentang halaman-halaman pada sistem yang digunakan untuk melakukan konsultasi, Gambar 5.

Antarmuka pemakai akhir dibuat menggunakan HTML, yang kemudian dikoneksikan dengan knowledge base yang telah dibuat dengan e2gRuleWriter (burung_air.kb) melalui mesin inferensi (e2gRuleEngine). Dikarenakan e2gLite Expert System Shell berbentuk Java Applet, maka kode applet tersebut perlu disisipkan di antara tagtag HTML agar antarmuka pemakainya dapat terlihat pada halaman web. Adapun bentuk source code dari applet tersebut adalah sebagai berikut:

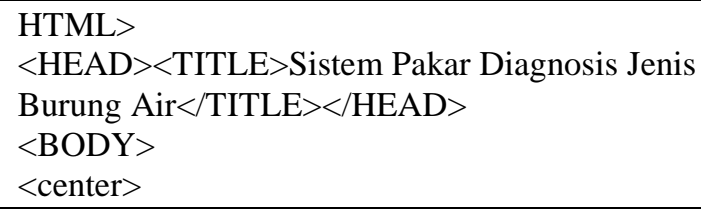

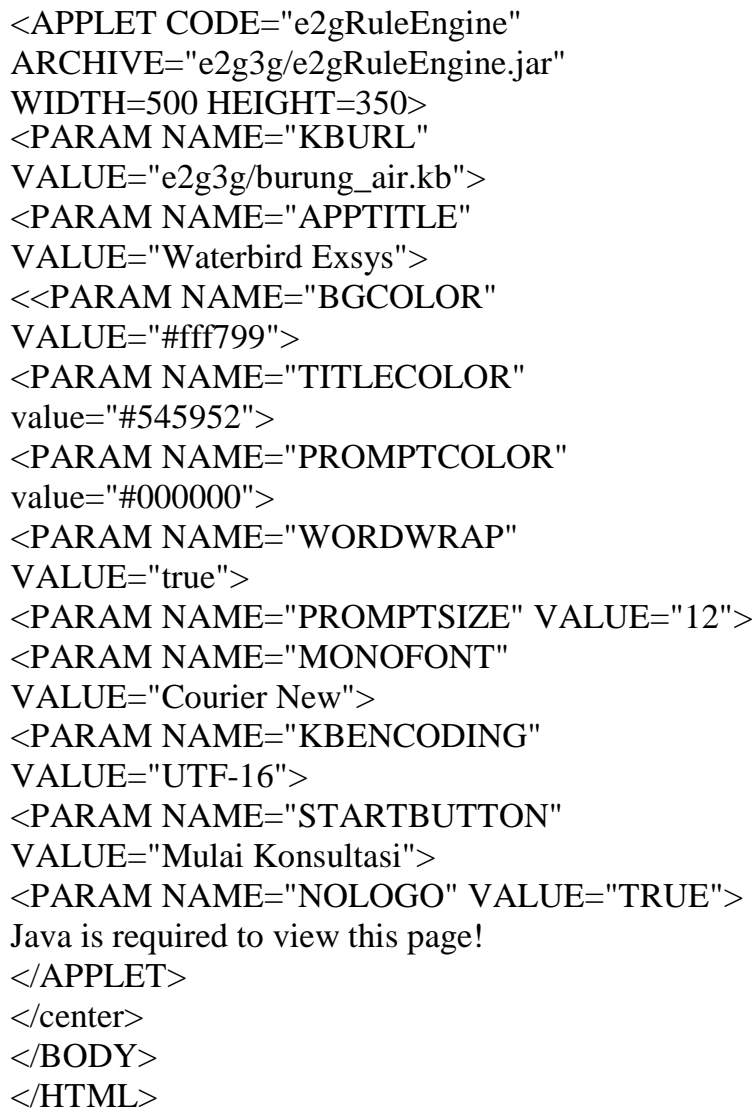

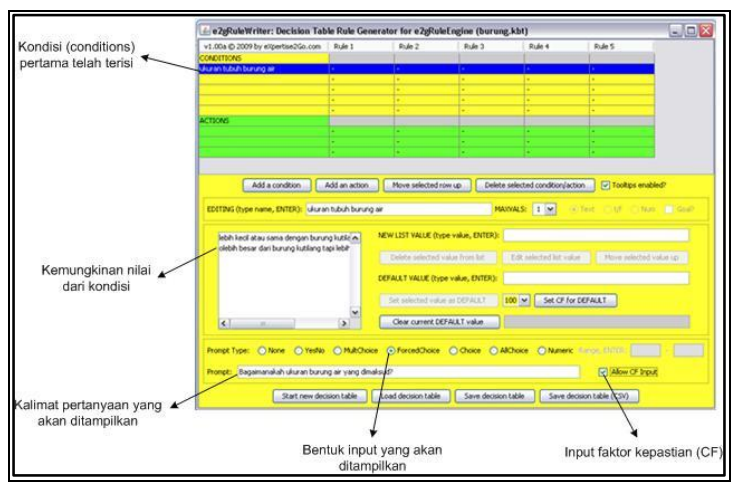

Gambar 3. Antarmuka modul e2gRuleWriter

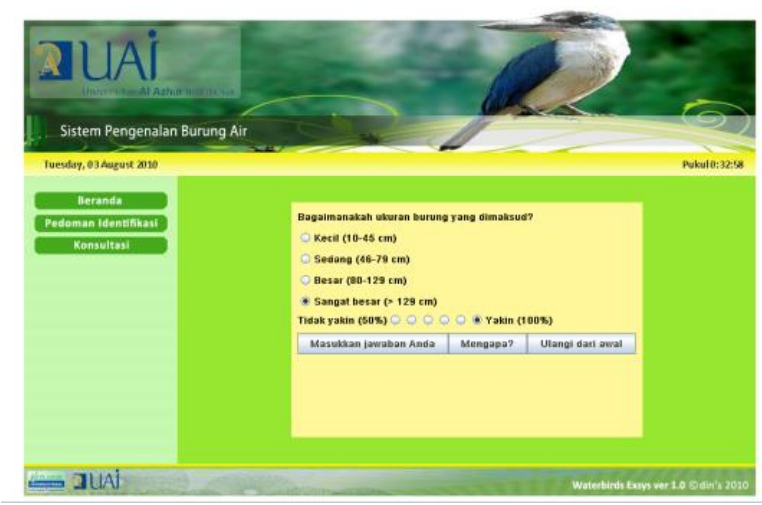

Gambar 4. Antarmuka Pemakai Akhir yang telah disisipkan Java Applet e2gRuleEngine 


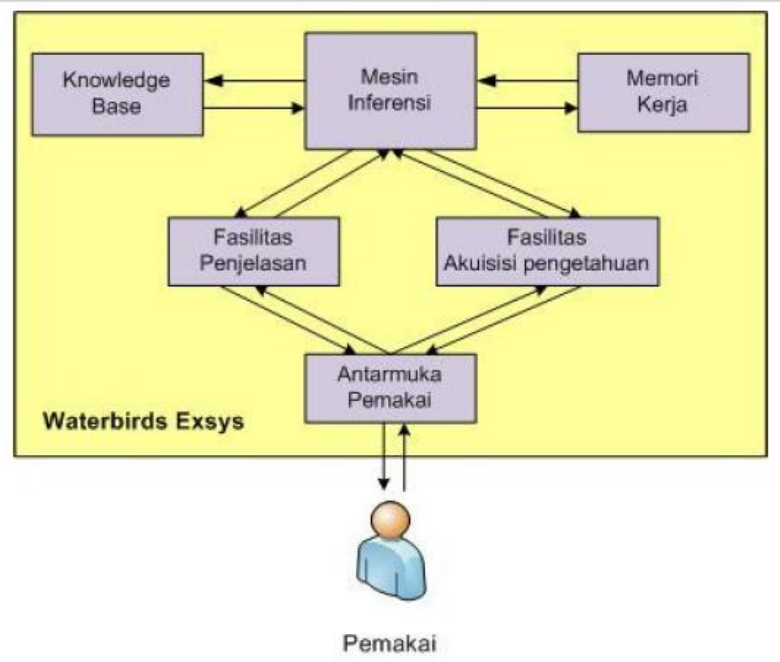

Gambar 5. Arsitektur WaterBird Exsys

\section{KESIMPULAN}

Dari hasil penelitian ini dapat diambil beberapa kesimpulan antara lain:

1. Dengan menggunakan metode rekayasa pengetahuan (akuisisi dan representasi), pengetahuan pakar di bidang burung air dapat dipetakan dan diformulasikan menjadi bentuk format yang dapat diterima oleh komputer.

2. Sistem Pakar Diagnosis Jenis Burung Air Berbasis Web (Waterbird Exsys) memiliki kemampuan untuk menyimpan pengetahuan para pakar di bidang burung air.

3. Sistem Pakar Diagnosis Jenis Burung Air Berbasis Web (Waterbird Exsys) dapat membantu untuk mengidentifikasikan jenis burung air, dan tidak terbatas tempat dan waktu selama pengguna terkoneksi dengan jaringan internet.

4. Pembuatan sistem pakar dengan menggunakan alat pengembangan shell sebagai dapat mempermudah pengembang karena tidak memerlukan programmer handal untukmembuat system pakar, sehingga lebih fokus pada basis pengetahuan yang dibangun. Shell memiliki keterbatasan dalam bentuk/format basis pengetahuan yang disediakan.

\section{UCAPAN TERIMAKASIH}

Penulis mengucapkan terima kasih kepada Dinas Pendidikan Tinggi Provinsi DKI Jakarta, yang telah memberikan bantuan dana pembinaan penelitian, sehingga penulis dapat menyelesaikan penelitian dengan baik. Disamping itu, penulis juga mendapatkan track record pengalaman dan keterampilan penelitian, serta dapat mengembangkan pengetahuan dalam dibidang penulis. Semoga Allah memberikan berkah dan balasan kebaikan yang berlipat ganda pada lembaga ini.

\section{DAFTAR PUSTAKA}

[1] Shahbaz Fahad Khan , Razzaq Saad, Irfan Kashif, Maqbool Fahad, Farid Ahmad, Illahi Inam, A`min Tauqeer ul, Dr. Wheat: A Web-based Expert System for Diagnosis of Diseases and Pests in Pakistani Wheat, Proceedings of the World Congress on Engineering Vol I WCE 2008, London, UK, July 2-4, 2008.

[2] Jain M. Babita, Jain Amit and M.B. Srinivas, A Web based Expert System Shell for Fault Diagnosis and Control of Power System Equipment, International Conference on Condition Monitoring and Diagnosis, Beijing, China, April 21-24, 2008.

[3] MacKinnon, John, Field Guide to the Birds of Java and Bali, Yogyakarta: Gajah Mada University Press, 1991

[4] Kusumadewi, Sri, Artificial Intelligence (Teknik dan Aplikasinya), Yogyakarta: Graha Ilmu, 2003.

[5] Hartati, Sri dan Sari Iswanti, Sistem Pakar dan Pengembangannya, Yogyakarta: Graha Ilmu, 2008.

[6] Suparman, Mengenal Artificial Intelligence, Yogyakarta: Penerbit Andi, 1991.

[6] Tomic Bojan, Jovanovic' Jelena *, and Devedz ic Vladan, JavaDON: an open-source expert system shell, Expert Systems with Applications 31, p.595606, 2006.

[7] Friedman-Hill Ernest J., Jess, The Expert System Shell for the Java Platform, http://herzberg.ca.sandia.gov/jess, Distributed Computing Systems Sandia National Laboratories Livermore, CA, Version 6.1RC1,24 March 2003.

[8] Handayani, Lina dan Sutikno, Tole, Sistem Pakar untuk Diagnosis Penyakit THT Berbasis Web dengan "e2gLite Expert System Shell", Jurnal Teknologi Industri Vol. XII No.1 Januari 2008: p.19-26, 2008.

[10] www.expertise2go.com, e2gRuleEngine/e2gRule WriterTutorial

[11] Negnevitsky, Michael, Artificial Intelligence A Guide to Intelligent System. $2^{\text {nd }}$ Edition. Addison Wesley, 2005.

[12] E. Lamma a;3 L. Maestrami 5 P. Mello b;1 F. Riguzzi a;2 S. Storari a;4, Rule-based Programming for Building Expert Systems: a Comparison in the Microbiological Data Validation and Surveillance Domain, Electronic Notes in Theoretical Computer Science 59 No.4 http://www.elsevier.n1/locate/entcs/volume59.htm1 5 pages, 2001. 


\section{LAMPIRAN}

Tabel 1. Perbandingan Alat Pengembangan Sistem Pakar

\begin{tabular}{|c|c|c|c|c|}
\hline Indikator & $\begin{array}{l}\text { 2egLite Expert } \\
\text { System Shell }\end{array}$ & JESS & PHP & Prolog \\
\hline $\begin{array}{l}\text { Waktu untuk } \\
\text { pengembangan }\end{array}$ & $\begin{array}{l}\text { Relatif singkat karena } \\
\text { sistem tidak dikembangkan } \\
\text { dari awal (komponen- } \\
\text { komponen sistem pakar } \\
\text { sudah tersedia) }\end{array}$ & $\begin{array}{l}\text { Memakan banyak waktu } \\
\text { (lama) karena system } \\
\text { dikembangkan dari awal }\end{array}$ & $\begin{array}{l}\text { Memakan banyak } \\
\text { waktu (lama) karena } \\
\text { system } \\
\text { dikembangkan dari } \\
\text { awal }\end{array}$ & $\begin{array}{l}\text { Memakan banyak } \\
\text { waktu (lama) karena } \\
\text { sistem dikembangkan } \\
\text { dari awal }\end{array}$ \\
\hline $\begin{array}{l}\text { Antarmuka } \\
\text { pemakai }\end{array}$ & $\begin{array}{l}\text { Telah didukung antarmuka } \\
\text { pemakai yang baik }\end{array}$ & $\begin{array}{l}\text { Belum didukung oleh } \\
\text { antarmuka pemakai, } \\
\text { sehingga pengembang } \\
\text { juga harus memuat } \\
\text { antarmuka yang sesuai }\end{array}$ & $\begin{array}{l}\text { Antarmuka pemakai } \\
\text { harus dikembangkan } \\
\text { sendiri }\end{array}$ & $\begin{array}{l}\text { Antarmuka pemakai } \\
\text { masih berbentuk seperti } \\
\text { command line }\end{array}$ \\
\hline $\begin{array}{l}\text { Kompatibilitas } \\
\text { web browser }\end{array}$ & $\begin{array}{l}\text { Dapat dijalankan melalui } \\
\text { web browser tetapi harus } \\
\text { menggunakan Java Plugins }\end{array}$ & $\begin{array}{l}\text { Dapat dijalankan melalui } \\
\text { web browser }\end{array}$ & $\begin{array}{l}\text { Dapat dijalankan } \\
\text { melalui web browser }\end{array}$ & $\begin{array}{l}\text { Tidak dapat dijalankan } \\
\text { melalui web browser }\end{array}$ \\
\hline $\begin{array}{l}\text { Teknik } \\
\text { Penelusuran }\end{array}$ & $\begin{array}{l}\text { Telah mendukung forward } \\
\text { dan backward chaining }\end{array}$ & $\begin{array}{l}\text { Telah mendukung forward } \\
\text { dan backward chaining }\end{array}$ & $\begin{array}{l}\text { Teknik penelusuran } \\
\text { harus dideklarasikan } \\
\text { (diciptakan) terlebih } \\
\text { dahulu }\end{array}$ & $\begin{array}{l}\text { Teknik penelusuran } \\
\text { harus dideklarasikan } \\
\text { (diciptakan) terlebih } \\
\text { dahulu }\end{array}$ \\
\hline $\begin{array}{l}\text { Kemudahan } \\
\text { modifikasi }\end{array}$ & Modifikasi terbatas & Mudah dimodifikasi & Mudah dimodifikasi & Mudah dimodifikasi \\
\hline
\end{tabular}

Tabel 2. Keputusan Jenis Burung Air

\begin{tabular}{|c|c|c|c|c|c|c|c|c|c|c|c|c|}
\hline No & $\begin{array}{l}\text { Kondisi } \\
\text { Tubuh }\end{array}$ & Jenis Burung & $\mathbf{A}$ & B & $\mathbf{C}$ & D & $\mathbf{E}$ & $\mathbf{F}$ & $\mathbf{G}$ & $\mathbf{H}$ & I & $\mathbf{J}$ \\
\hline 1 & Ukuran Tubuh & $\begin{array}{l}\text { Lebih kecil atau sama dengan burung kutilang } \\
(<20 \mathrm{~cm})\end{array}$ & & & & & & & & & & \\
\hline 2 & Ukuran Tubuh & $\begin{array}{l}\text { Lebih besar dari burung kutilang tapi lebih kecil } \\
\text { dari bebek }(20-39 \mathrm{~cm})\end{array}$ & $\bullet$ & $\bullet$ & & & & & & & & \\
\hline 3 & Ukuran Tubuh & $\begin{array}{l}\text { Lebih besar dari bebek tapi lebih kecil dari } \\
\text { angsa }(40-79 \mathrm{~cm})\end{array}$ & & & $\bullet$ & $\bullet$ & $\bullet$ & & & & & \\
\hline 4 & Ukuran Tubuh & Lebih besar dari angsa $(\geq 80 \mathrm{~cm})$ & & & & & & $\bullet$ & $\bullet$ & $\bullet$ & $\bullet$ & $\bullet$ \\
\hline 5 & Bentuk Tubuh & Seperti bebek/mentok(duck-like) & $\bullet$ & $\bullet$ & & & & & $\bullet$ & $\bullet$ & $\bullet$ & \\
\hline 6 & Bentuk Tubuh & Seperti ayam (chicken-like-marsh) & & & & & & & & & & \\
\hline 7 & Bentuk Tubuh & Seperti camar ( gull-like) & & & & & & & & & & \\
\hline 8 & Bentuk Tubuh & Seperti burung pantai/kedidi (shorebird-like) & & & & & & & & & & \\
\hline 9 & Bentuk Tubuh & Seperti bangau/kuntul (long-legged-like) & & & & & & & & & & $\bullet$ \\
\hline 10 & Bentuk Tubuh & Seperti pecuk (upright-perching Water-like) & & & $\bullet$ & $\bullet$ & $\bullet$ & & & & & \\
\hline 11 & Ukuran Paruh & Lebih pendek dari kepala & $\bullet$ & $\bullet$ & & & & & & & & \\
\hline 12 & Ukuran Paruh & Sama dengan kepala & & & $\bullet$ & $\bullet$ & $\bullet$ & & & & & \\
\hline 13 & Ukuran Paruh & Lebih panjang dari kepala & & & & & & $\bullet$ & $\bullet$ & $\bullet$ & $\bullet$ & $\bullet$ \\
\hline 14 & Bentuk paruh & Seperti sendok (pipih dan melebar di ujungnya) & & & & & & & & & & \\
\hline 15 & Bentuk paruh & Pipih & & & & & & & & & & \\
\hline 16 & Bentuk paruh & Besar dan berkantung & & & & & & & $\bullet$ & $\bullet$ & $\bullet$ & \\
\hline 17 & Bentuk paruh & $\begin{array}{l}\text { Ramping/agak besar dan paruh atas sedikit } \\
\text { melengkung }\end{array}$ & $\bullet$ & $\bullet$ & $\bullet$ & $\bullet$ & $\bullet$ & & & & & \\
\hline 18 & Bentuk paruh & Besar dan paruh atas sedikit melengkung & & & & & & & & & & \\
\hline 19 & Bentuk paruh & Ramping dan lurus & & & & & & & & & & \\
\hline 20 & Bentuk paruh & Agak besar dan lurus & & & & & & $\bullet$ & & & & $\bullet$ \\
\hline 21 & Bentuk paruh & Besar dan lurus & & & & & & & & & & \\
\hline 22 & Bentuk paruh & Ramping dan melengkung ke bawah & & & & & & & & & & \\
\hline \multicolumn{13}{|c|}{ Keterangan simbol A-J: } \\
\hline \multicolumn{2}{|c|}{ A: Australasian Grebe } & F: Oriental Darter & & & & & & & & & & \\
\hline \multicolumn{2}{|c|}{ B: Little Grebe } & G: Great White Pelican & & & & & & & & & & \\
\hline \multicolumn{2}{|c|}{ C: Little Black Cormorant } & H: Spot-billed Pelican & & & & & & & & & & \\
\hline \multicolumn{2}{|c|}{ D: Little Pied Cormorant } & I: Australian Pelican & & & & & & & & & & \\
\hline \multicolumn{2}{|c|}{ E: Little Cormorant } & J: Grey Heron & & & & & & & & & & \\
\hline
\end{tabular}

